\title{
TOKSISITAS SENYAWA FENOL TERHADAP KELANGSUNGAN HIDUP IKAN MAS (CYPRINUS CARPIO)
}

\author{
Maria Aloisia Uron Leba ${ }^{1, *}$, Claudia Mariska Mardikawati Maing ${ }^{2}$ \\ ${ }^{1}$ Program Studi Kimia, Universitas Katolik Widya Mandira, Jl. Merdeka Lama, Kupang, 85225, Indonesia \\ ${ }^{2}$ Program Studi Fisika, Universitas Katolik Widya Mandira, Jl. Merdeka Lama, Kupang, 85225, Indonesia \\ *Author Utama, email: mariaaloisiauronleba@gmail.com \\ Co-author 1, email: claudia.maing@yahoo.com
}

\begin{abstract}
Goldfish (cyprinus carpio) is one of freshwater fish that became the main source of protein. Freshwater fish are generally bred in ponds, lakes or reservoirs that the river passes through. Unfortunately the condition of the river water is currently quite concerned due to the entry of various wastes into the river. Phenols and their derivatives are one of the pollutants found in air, soil, and sediments. This presence in the air environment can disrupt the integrity of the air ecosystem and is very damaging to its organisms. This compound is toxic to fish because it can cause genotoxic, carcinogenic, immunotoxic, and bioaccumulation lead. This study aims to determine the toxicity of phenol compounds to the survival of carp conducted in controlled containers. Based on the research results can be seen the increase in the concentration of phenol in the air, high levels of life cyprinus carpioarah low. From this study also produced the content of phenol in air to live cyprinus carpio at a concentration of $2.4 \mathrm{ppm}$. At this concentration the survival rate of cyprinus carpio reaches $100 \%$
\end{abstract}

Keywords: Phenol, Goldfish, Cyprinus caprio, Toxicity

ABSTRAK

Ikan mas (cyprinus carpio) merupakan salah satu jenis ikan air tawar yang menjadi sumber utama protein. Ikan air tawar umumnya dikembangbiakkan pada kolam, danau atau waduk yang dilalui aliran sungai. Sayangnya kondisi air sungai saat ini cukup memprihatin diakibatkan oleh masuknya berbagai limbah ke dalam sungai. Fenol dan senyawa turunannya merupakan salah satu bahan pencemar yang ditemukan dalam air, tanah, dan sedimen. Keberadaan senyawa ini dalam lingkungan air dapat menggganggu keutuhan ekosistem air dan sangat berbahaya terhadap organisme - organismenya. Senyawa ini bersifat toksit terhadap ikan karena dapat menyebabkan genotoxic, carcinogenic, immunotoxic, dan berpotensi menyebabkan bioakumulasi. Penelitian ini bertujuan untuk mempelajari toksisitas senyawa fenol terhadap kelangsungan hidup ikan mas yang dilakukan dalam wadah terkontrol. Berdasarkan hasil penelitian dapat diketahui bahwa semakin tinggi konsentrasi senyawa fenol dalam air, tingkat kelangsungan hidup cyprinus carpio semakin rendah. Dari penelitian ini pula diperoleh batas aman keberadaan senyawa fenol dalam air terhadap kelangsungan hidup cyprinus carpio adalah pada konsentrasi 2,4 ppm. Pada konsentrasi ini tingkat kelangsungan hidup cyprinus carpio mencapai $100 \%$.

Kata Kunci: Fenol, Ikan Mas, Cyprinus Carpio, Toksisitas 


\section{PENDAHULUAN}

Ikan mas (cyprinus carpio) merupakan salah satu jenis ikan air tawar yang menjadi sumber utama protein dan tersebar luas di seluruh Indonesia. Ikan air tawar umumnya dikembangbiakkan pada kolam, danau atau waduk yang dilalui aliran sungai. Asupan bahan makanan dan kualitis air sebagai media hidup merupakan faktor yang sangat mempengaruhi perkembangbiakan ikan dan kualitas daging ikan yang dihasilkan. Sayangnya kondisi air sungai saat ini cukup memprihatin terutama pada daerah perindustrian, pabrik, persawaahan dan pemukiman penduduk. Pencemaran air sungai diakibatkan oleh masuknya berbagai limbah industri, pabrik, pertanian, rumah sakit dan rumah tangga ke dalam sungai.

Senyawa fenol dan turunannya digunakan secara luas dalam berbagai bidang seperti farmasi, industri dan pabrik (bahan kimia, obat-obatan, tekstil, kertas), sebagai penseril peralatan kedokteran yang digunakan dalam rumah sakit serta berbagai produk pembersih rumah tangga (desinfektan). Limbah berbagai produk yang mengandung senyawa ini umumnya dilepaskan secara bebas ke lingkungan. Hal ini terjadi karena masih minimnya informasi bagi masyarakat mengenai kandungan senyawa fenol dalam berbagai produk serta bahayanya bagi lingkungan dan kesehatan mananusia.

Fenol dan senyawa turunannya merupakan salah satu bahan pencemar yang ditemukan dalam air, tanah, dan sedimen [6]. Keberadaan senyawa ini dalam lingkungan air dapat menggganggu keutuhan ekosistem air dan sangat berbahaya terhadap organisme - organismenya [5]. Senyawa ini bersifat toksit terhadap ikan karena dapat menyebabkan genotoxic, carcinogenic, immunotoxic, dan berpotensi menyebabkan bioakumulasi [8].

Dalam lingkungannya, ikan dan organisme perairan lainnya beriteraksi secara normal. Bila lingkungan hidup berubah, seluruh organisme yang hidup di dalamnya turut mengalami perubahan. Dengan demikian ketika lingkungan perairan tercemar akan berdampak pada kehidupan ikan dan organisme lainnya yang berhabitat di dalamnya. Pencemaran senyawa fenol dengan kadar yang tinggi dapat menyebabkan toksisitas pada organism air termasuk ikan.

Berdasarkan uraian diatas maka perlu dilakukan penelitian untuk mengkaji toksisitas senyawa fenol terhadap kelangsungan hidup ikan mas.

\section{METODE PENELITIAN}

\section{Material}

Untuk keperluan uji pendahuluan dan stimulasi, dibuat larutan induk fenol 1000 ppm. Larutan standar fenol 1000 ppm dibuat dengan menimbang 1 gram (1000 mg) fenol, dilarutkan dan diencerkan dengan aguades dalam labu takar $1 \mathrm{~L}$ hingga tepat tanda batas. Pekerjaan ini dilakukan dengan cepat karena fenol sangat higroskopis.

\section{Instrumentasi}

Dalam preparasi larutan digunakan alatalat gelas standar yang umumnya digunakan di laboratorium kimia. Dalam persiapan dan preparasi sampel digunakan alat-alat 
pendukung berupa wadah hidup ikan (aquarium), pisau, blender, indikator universal, thermometer,botol reagen, kertas saring.

\section{Prosedur}

\section{Persiapan Habitat Sementara Hewan Uji}

Habitat sementra hewan uji (kolam ) dibuat dari semen dengan ukuran 2,5 $\mathrm{m} \times 0,5$ $\mathrm{m} \times 0,5 \mathrm{~m}$. Selanjutnya dilakukan perawatan dan uji coba penggunaan kolam. Perawatan dilakukan dengan cara memasukan air hingga penuh dan dibiarkan selama 1 minggu kemudian dibersihkan. Uji coba dilakukan dengan cara membiarkan hewan uji di dalam kolam selama 3 minggu untuk memastikan kolam layak digunakan. Selanjutnya hewan uji dihidupkan di dalam kolam selama 1 minggu sebelum digunakan dalam penelitian.

\section{Pembuatan Larutan Standar}

Untuk keperluan uji pendahuluan dan stimulasi, dibuat larutan induk fenol 1000 ppm. Larutan standar fenol 1000 ppm dibuat dengan menimbang 1 gram (1000 mg) fenol, dilarutkan dan diencerkan dengan aguades dalam labu takar $1 \mathrm{~L}$ hingga tepat tanda batas. Pekerjaan ini dilakukan dengan cepat karena fenol sangat higroskopis.

\section{Uji Pendahuluan}

Uji pendahuluan bertujuan untuk memperoleh konsentrasi terendah senyawa fenol yang

tidak menyebabkan kematian yang kemudian menjadi konsentrasi batas bawah dan konsentrasi senyawa fenol yang menyebabkan kematian terbanyak pada hewan uji yang kemudian menjadi konsentrasi batas atas. Uji pendahuluan dilakukan pada berbagai konsentrasi senyawa fenol yakni 20 ppm, 22 ppm, 24 ppm, 26 ppm, 28 ppm, dan 30 ppm. Sebanyak 36 hewan uji dibagi menjadi 6 perlakuan, masing-masing perlakuan membutuhkan 6 ekor hewan uji. Kedalam ke 6 buah wadah/aquarium dimasukan $5 \mathrm{~L}$ air yang mengandung 20 ppm, 22 ppm, 24 ppm, 26 ppm, 28 ppm, dan 30 ppm senyawa fenol. Lamanya perlakuan adalah 24 jam. Setelah 24 jam diamati jumlah hewan uji yang mati pada setiap perlakuan. Pada tahap uji pendahuluan dilakukan pengulangan sebanyak 3 kali.

\section{Uji Akut}

Berdasarkan hasil uji pendahuluan, diperoleh konsentrasi senyawa fenol yang menjadi batas atas yakni $30 \mathrm{ppm}$ dan batas bawah yakni $20 \mathrm{ppm}$. Tahap selanjutnya adalah uji akut senyawa fenol terhadap hewan uji. Pada uji ini dibuat 4 macam perlakuan dengan konsentrasi yang berbeda. Penentuan ke-4 konsentrasi ini dihitung berdasarkan rumus:

$\log (N / n)=k \log (a / n)[9]$

Dengan

$\mathrm{N}=$ konsentrasi batas atas

$\mathrm{n}=$ konsentrasi batas bawah,

$\mathrm{a}=$ konsentrasi terkecil dalam deret konsentrasi yang ditentukan dan

$\mathrm{k}=$ jumlah interval konsentrasi yang diuji.

Dengan demikian uji akut dilakukan pada konsentrasi 21,7 ppm, 23,5 ppm, 27,6 ppm dan 38,1 ppm.

Sebanyak 24 hewan uji dibagi menjadi 4 perlakuan, masing-masing perlakuan 
membutuhkan 6 hewan uji. Lamanya perlakuan adalah 96 jam atau 4 hari.

\section{Uji Kronis}

Uji ini bertujuan untuk mengetahui paparan senyawa fenol terhadap perubahan fisik hewan uji (organ insang, hati, ginjang dan jaringan otot). Berdasarkan uji akut dan hasil analisis diperoleh batas aman penggunaan senyawa fenol sebagai bahan pencemar. Pada tahan ini digunakan 3 variasi konsentrasi yaitu konsentrasi dibawah batas aman, konsentrasi aman dan konsentrasi diatas batas aman. Konsentrasi batas aman dihitung sebagai berikut:

Batas aman $=10 \% \times$ LC 96 jam ...

Dengan LC 50-96 jam adalah konsentrasi dibawah batas atas dengan jumlah kematian hewan uji terbanyak.

Berdasarkan uji akut diperoleh LC 50-96 jam adalah 23,5 ppm dan berdasarkan perhitungan diatas diperoleh konsentrasi batas aman penggunaan senyawa fenol adalah 2,35 ppm. Konsentrasi dibawah batas aman dan diatas batas aman dipilih yakni 1 ppm dan 5 ppm.

Sebanyak 18 hewan uji dibagi menjadi 3 perlakuan. Lamanya perlakuan adalah 6 minggu. Setelah 6 minggu sampel diambil dan diamati keadaan fisik (sisik, mata) dan organ insang..

\section{HASIL DAN PEMBAHASAN}

Toksisitas senyawa fenol terhadap hewan uji yakni ikan mas dipelajari melalui beberapa perlakuan yakni uji pendahuluan, uji akut dan uji kronis.

\section{Uji Pendahuluan metode Range Finding Test (RFT)}

Uji pendahuluan yang digunakan dalam penelitian ini adalah menggunakan metode range finding test (RFT) yaitu suatu metode untuk memperkirakan konsentrasi fenol yang tidak menyebabkan kematian hingga menyebabkan kematian terbanyak [Yuniar, 2012]. Uji ini dilakukan selama 24 jam.

Berdasarkan perlakuan untuk menentukan nilai RFT diperoleh konsentrasi senyawa fenol yang tidak menyebabkan kematian pada hewan uji yaitu pada konsentrasi 20 ppm sedangkan konsentrasi yang menyebabkan kematian terbanyak yaitu pada konsentrasi 30 ppm yakni $72,2 \%$, seperti yang ditunjukan dalam Tabel 3 . Berdasarkan Tabel 3 diketahui pula bahwa semakin besar konsentrasi senyawa fenol semakin besar pula persentase kematian pada hewan uji.

Tabel 1. Hewan Uji yang Mati pada Uji Pendahuluan

\begin{tabular}{|c|c|c|c|c|c|}
\hline \multirow{2}{*}{$\begin{array}{c}\text { C } \\
\text { fenol } \\
\text { (ppm) }\end{array}$} & \multicolumn{3}{|c|}{$\begin{array}{l}\text { Hewan uji yang } \\
\text { mati (ekor) pada } \\
\text { pengulangan ke- }\end{array}$} & \multirow[t]{2}{*}{$\begin{array}{l}\text { Rata- } \\
\text { rata }\end{array}$} & \multirow[t]{2}{*}{$\begin{array}{c}\% \\
\text { kematiar }\end{array}$} \\
\hline & 1 & 2 & 3 & & \\
\hline 20 & 0 & 0 & 0 & 0 & 0 \\
\hline 22 & 1 & 0 & 1 & 0,67 & 11,2 \\
\hline 24 & 4 & 1 & 1 & 2 & 33,3 \\
\hline 26 & 3 & 3 & 2 & 2,67 & 44,5 \\
\hline 28 & 5 & 3 & 4 & 4 & 66,7 \\
\hline 30 & 4 & 5 & 4 & 4,33 & 72,2 \\
\hline
\end{tabular}


Tabel 4. Tingkat Kelangsungan Hidup Hewan Uji pada Uji Akut pada 6 ekor ikan mas

\begin{tabular}{|c|c|c|c|c|c|c|}
\hline \multirow{2}{*}{$\begin{array}{l}\text { Konsentrasi } \\
\text { Fenol (ppm) }\end{array}$} & \multicolumn{4}{|c|}{$\begin{array}{l}\text { Jumlah ikan yang mati } \\
\text { (ekor) pada hari ke- }\end{array}$} & \multirow{2}{*}{$\begin{array}{l}\text { Jumlah total ikan yang } \\
\text { mati (ekor) setelah } 96 \\
\text { jam }\end{array}$} & \multirow{2}{*}{$\begin{array}{c}\text { Tingkat } \\
\text { kelangsungan } \\
\text { hidup (\%) }\end{array}$} \\
\hline & 1 & 2 & 3 & 4 & & \\
\hline 21,7 & 0 & 0 & 0 & 0 & 0 & 100 \\
\hline 23,5 & 0 & 2 & 0 & 1 & 3 & 50 \\
\hline 27,6 & 0 & 0 & 2 & 2 & 4 & 33.3 \\
\hline 38,1 & 6 & - & - & - & 6 & 0 \\
\hline
\end{tabular}

Senyawa fenol merupakan salah satu senyawa yang bersifat racun yang dapat menyebabkan kematian pada jangkauan konsentrasi yang cukup tinggi. Pada konsentrasi yang rendah dapat menyebabkan gangguan sistem peredaran darah, iritasi selaput lendir dan pecahnya sel darah merah. Perlakuan senyawa fenol yang diberikan pada hewan uji pada uji pendahuluan dapat mengakibatkan kematian dengan persentase kematian yang bervariasi berdasarkan konsentrasi yang diberikan. Pada konsentrasi 22 ppm persentase kematian pada hewan uji mencapai $11,2 \%$ dan meningkat menjadi $72,2 \%$ pada konsentrasi $30 \mathrm{ppm}$. Data ini menjelaskan bahwa masih terdapat sejumlah hewan uji yang dapat bertahan hidup pada perlakuan ini. Hal ini terjadi karena setiap hewan uji mempunyai sistem imun yang berbeda-beda. Hewan uji yang mempunyai sistem imun yang baik akan mampu bertahan hidup sedangkan hewan uji yang mempunyai sistem imun yang kurang baik tidak akan bertahan hidup.

Kematian pada hewan uji akibat perlakuan dengan senyawa fenol disebabkan oleh disfungsi organ-organ tertentu akibat masuknya senyawa fenol ke dalam tubuh. Masuknya senyawa fenol ke dalam tubuh hewan uji dapat terjadi melalui penetrasi kedalam tubuh lewat kulit yang mengakibatkan pecahnya sel darah merah. Kematian pada hewan uji juga dapat diakibatkan rusaknya jaringan insang akibat paparan senyawa fenol pada konsentrasi yang cukup tinggi. Rusaknya jaringan insang dapat mengakibatkan terganngunya proses pengambilan oksigen dan peningkatan frekwensi pernapasan dari keadaan normal.

\section{Uji Akut}

Uji akut merupakan uji makluk hidup terhadap suatu keadaan yang cukup parah sehingga menyebabkan suatu respon yang cepat biasanya selama 4 hari atau 96 jam. Dalam uji ini dirancang untuk menentukn konsentrasi letal median (LC50) toksikan. LC50 didefinisikan sebagai dosis tunggal suatu zat yang secara statistik diharapkan akan membunuh hewan uji sebanyak $50 \%$ dari jumlah populasi. Pengujian ini bertujuan untuk memberikan petunjuk tentang konsentrasi yang sebaiknya digunakan pada pengujian yang lebih lama.

Konsentrasi yang digunakan dalam uji akut adalah 21,7 ppm, 23,5 ppm, 27,6 ppm dan 38, 1 ppm. Tingkat kelangsungan hidup hewan uji pada uji akut ditampilkan dalam Tabel 4.

Berdasarkan data pada Tabel 4 dapat diketahui pula tingkat kelangsungan hidup hewan uji dalam setiap perlakuan selama 4 
hari. Tingkat kelangsungan hidup paling tinggi adalah pada konsentrasi 21,7 ppm yaitu sebesar $100 \%$. Pada konsentrasi ini semua hewan uji mampu beradaptasi terhadap perubahan lingkungan akibat keberadaan senyawa fenol dalam media hidupnya. Pada konsentrasi 38,1 ppm tingkat kelangsungan hidup hewan uji $0 \%$. Pada konsentrasi ini semua hewan uji tidak dapat bertahan hidup selama 24 jam. Ini menunjukan bahwa hewan uji tidak mampu beradaptasi karena tingginya konsentrasi senyawa fenol yang diberikan. Pada konsentrasi 23,5 ppm dan 27,6 ppm tingkat kelangsungan hidup hewan uji mencapai $50 \%$ dan 33,3\%. Pada konsentrasi 23,5 ppm semua hewan uji hanya dapat bertahan hidup selama 1 hari, pada hari kedua mulai terdapat hewan uji yang mati, sedangkan pada konsentrasi 27,6 ppm semua hewan uji dapat bertahan hidup hingga hari ke 2 dan pada hari ke 3 mulai terdapat hewan uji yang mati. Data ini menunjukan bahwa pada kedua konsentrasi ini hewan uji masih dapat beradaptasi terhadap perubahan lingkungan, namun kemampuan untuk beradaptasi ini bergantung pada imunitas hewan uji. Hewan uji yang mempunyai sistem imun yang baik akan mampu bertahan hidup hingga akhir perlakuan.

Berdasarkan Tabel 4 pula dapat diketahui bahwa pemberian konsentrasi fenol berpengaruh secara signifikan terhadap kelangsungan hidup hewan uji, dimana semakin tinggi konsentrasi fenol yang diberikan menyebabkan semakin rendah tingkat kelangsungan hidup. Dari uji akut ini diperoleh nilai LC 50-96 jam yaitu pada konsentrasi 23,5 ppm.
Selain kelangsungan hidup hewan uji, parameter lain yang juga diamati pada uji akut adalah kualitas air yakni suhu dan $\mathrm{pH}$. Suhu air selama perlakuan adalah $28^{\circ} \mathrm{C}$ sedangan pHnya adalah 7 baik pada awal maupun akhir perlakuan. Kondisi ini termasuk dalam kondisi normal bagi kelangsungan hidup ikan mas. Dengan demikian kelangsungan hidup hewan uji selama perlakuan hanya dipengaruhi oleh keberadaan senyawa fenol dalam media hidup hewan uji.

\section{Uji Kronis}

Pada uji ini digunakan 3 variasi konsentrasi senyawa fenol yaitu konsentrasi batas aman, dibawah batas aman dan diatas batas aman. Konsentrasi batas aman senyawa fenol untuk keberlangsungan hidup hewan uji adalah 2,35. Konsentrasi ini diperoleh berdasarkan uji akut. Konsentrasi dibawah batas aman dan konsentrasi diatas batas aman dipilih secara acak sebagai pembanding yakni $1 \mathrm{ppm}$ dan $5 \mathrm{ppm}$.

Tingkat kelangsungan hidup hewan uji pada uji kronis dipelajari selama 6 minggu. Data tingkat kelangsungan hewan uji pada uji kronis ditampilkan dalam Tabel 5.

Tabel 5. Tingkat Kelangsungan Hidup Hewan Uji pada Uji Kronis setelah 6 minggu

\begin{tabular}{ccc}
\hline $\begin{array}{c}\text { Konsentrasi } \\
\text { Fenol (ppm) }\end{array}$ & $\begin{array}{c}\text { Jumlah ikan } \\
\text { yang mati } \\
\text { (ekor) }\end{array}$ & $\begin{array}{c}\text { Tingkat } \\
\text { kelangsungan } \\
\text { hidup }\end{array}$ \\
\hline $\mathbf{1}$ & 0 & 100 \\
\hline $\mathbf{2 , 4}$ & 0 & 100 \\
\hline $\mathbf{5}$ & 0 & 100 \\
\hline
\end{tabular}

Dari Tabel 6 dapat dilihat tingkat kelangsungan hidup hewan uji pada setiap variasi konsentrasi yang diberikan. Tingkat 
kelangsungan hidup hewan uji selama perlakuan mencapai 100 \%. Hal ini disebabkan karena konsentrasi yang diberikan merupakan konsentrasi batas aman keberadaan senyawa fenol bagi kelangsungan hidup hewan uji dan konsentrasi disekitar batas aman yakni 1 ppm dan 5 ppm. Berdasarkan hasil yang diperoleh, tidak terdapat perbedaan tingkat kelangsungan hidup hewan uji pada konsentrasi batas aman dan konsentrasi disekitar batas aman.

Dalam uji ini, media hidup hewan uji (air yang mengandung senyawa fenol) diganti setiap 2 hari. Hal ini bertujuan agar konsentrasi senyawa fenol dalam air selama perlakuan tidak berubah. Suhu dan $\mathrm{pH}$ air selama perlakuan ini diukur setiap 2 hari yakni sebelum dan setelah pergantian air. Kadar keasaman atau $\mathrm{pH}$ air selama perlakuan adalah 7 sedangkan suhu air adalah $28^{\circ} \mathrm{C}$.

\section{KESIMPULAN}

Berdasarkan hasil penelitian ini dapat disimpulkan bahwa toksisitas senyawa fenol terhadap kelangsungan hidup ikan mas (cyprinus carpio) bervariasi bergantung pada konsentrasinya. Konsentrasi senyawa fenol yang menjadi batas aman bagi keberlangsungan hidup ikan mas adalah 2,4 ppm

\section{DAFTAR PUSTAKA}

[1] Cretu, C.R., Crisu, A., Oancea S., Turtureanu A., Pacala M.L. 2011. Enviromental Aspects of Purification of Phenolic Waste Waters by Mediated Electrooxidation with $\mathrm{Ce}+4 \mathrm{Ce}+3$ and Monitored by HPL. Journal of Food Tecnologi. XV.

[2] Dewilda, Y., Afrianita, R., Fadhila I. 2012. Degradasi Senyawa Fenol oleh Mikroorganisme Laut. Jurnal Teknik Lingkungan UNAND. 1:59-73.

[3] Gad, N.S., Saad A.S. 2008. Effect of Enviromental Pollution by Phenol on some Physiological Parameters of Oreochromis Niloticus. Journal of Global Veterinaria. 2 (6): 312-319.

[4] Grynkiewicz, M., Polkowska, Z.,Wasik, K., Namiesnik, J. 2008. Determination of Phenol in Runoff, Journal of Enviromental Studies. 11:85-89.

[5] Ibrahem, D.M. 2012. Experimental exposure of African catfish Clarias Gariepinus (Burchell, 1822) to phenol: Clinical evaluation, tissue alterations and residue assessment. Journal of Advanced Research. 3:177-183.

[6] Opeolu, B. O., Fatoki, O.S., Odendaal, J. 2010. Development of A Solid-Phase Extraction Methode Followed by HPLC-UV Detection for the Determination of Phenols in Water. International Journal of the Physical Sciences. 5(5):576-581.

[7] Santana, C.M., Ferrera, Z.S., Rodriguez, J.S. 2008. A New and Fast Extraction Method for the Determination of Priority Phenols from Marine Sediments by Liquid Chromatography. Journal of Chromatogrphy science. 43. 282-288.

[8] Zaki, S.M., M. Olfat., Shalaby, S.I. 2011. Phenol Toxicity Affecting Hematological Changes in Cat Fish (Clarius lazera). Journal Life Science. 8 (2).

[9] Vika Yuniar (2012), toxicity of mercury $(\mathrm{Hg})$ on survival and growth rate and histophatalogical parameters of oreochromis niloticus. J. Akuakultur Indonesia 11 (1) 38-4 